\title{
Petition warns of pending global environmental crisis
}

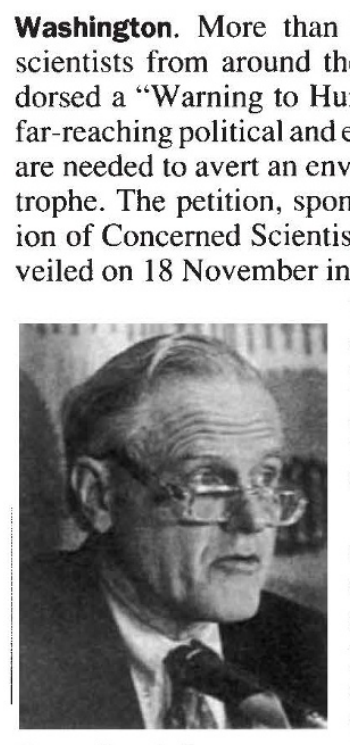

Henry Kendall
1,500 prominent rld have ennomic changes mental catasred by the Un(UCS) and untakes aim at a host of environmental problems from global warming to overpopulation.

A l t hough such petitions are common, UCS says that its fourpage document is distinguished by the unusually large number of signers, among them 98 Nobel prizewinners. It calls for a more efficient use of resources and an end to activities that damage the environment. Its goals, including eliminating poverty and giving "women control over their own reproductive decisions", would be funded in part with money now spent on military defence. The petition is being sent to government leaders around the world.

Supporters, including dozens from the developing world and many who seldom lend their names to causes outside their profession, say they were attracted by the broad scope of the petition and its vague but ambitious recommendations, which range from eliminating poverty to ensuring sexual equality. The even-handed tone of the petition, which blames both developing and developed nations for environmental damage, also appealed to many.

Some of the petition's statements are open to scientific debate. For example, it declares that "acid [rain] precipitation is causing widespread injury" and that ozone depletion is a "critical stress" to the environment. The petition acknowledges that the effects of global warming are still unclear but says that "uncertainty...cannot excuse complacency or delay in facing the threats".

Henry Kendall, a Nobel prizewinner in physics and chairman of the UCS, says that the organizers gathered the endorsements of scientists from different fields "to verify the aggregate pieces" of the petition. Edward $O$. Wilson, a Crafoord prize-winning biologist at Harvard, says it would have been "poor citizenship" to say that " "I don't speak to things outside my field.' There comes a time when scientists have to assume at least minimal responsibility." Traci Watson

\section{Biotechnology soared and fell in a roller-coaster 12 months}

Washington. A report by stock market analysts on the past year in US biotechnology which most companies are still losing money despite improving financial indicators. The availability and cost of new capital and an unpredictable regulatory environment continue to be a concern.

The report* points out that in the year ending June 1992 the industry raised more than US $\$ 3$ billion in public equity, exceeding the total for the entire decade of the 1980s. In January, Amgen Inc. of Thousand Oaks, California, became the first biotechnology company to be included in the Fortune 500 business list, with sales of $\$ 645$ million in 1991, largely from its first two products, Epogen and Neupogen.

But other companies were not so fortunate. In April, Centocor Inc. of Malvern, Pennsylvania, failed to win approval from the US Food and Drug Administration (FDA) for the company's main product, Centoxin (a human monoclonal antibody for the treatment of Gram-negative sepsis), and its stock price plummeted. It was also a year in which, despite an increase of 29 per cent in revenues for public companies (to $\$ 4.5$ billion), four out of five publicly held companies lost money and do not expect to make a profit before the middle of the decade.

Increasingly, companies are trying to accelerate commercialization and spread their risk. By acquiring licences for latestage technologies from other companies and by exchanging products, companies are generating revenues in the short-term and improving their chances of survival. Through acquisitions, partnerships and strategic alliances, they are acquiring manufacturing capabilities and sales forces to produce and distribute their own lines.

The report's coauthor, G. Steven Burrill of Ernst \& Young, found that strategic alliances are occurring earlier, often before a company goes public and sometimes even before it tries to obtain venture capital. These alliances add value and credibility to a company before it goes public.

The past year saw little change in the demographics of the industry; smaller-sized companies still predominate, with 76 per cent of companies having 50 or fewer employees. There have been double-digit percentage increases in both the number of companies and numbers of employees, to 1,231 and 79,000 respectively. As in the past few years, when the industry is broken down by market sector, the survey found that more companies are specializing in human health care than all other market segments combined.

Although there has been little change in reflects the mixed fortunes of an industry in the geographical landscape, with the San Francisco, New York and Boston areas having the largest concentration of companies, Burrill says that there has been considerable activity in the Seattle and San Diego areas and some around Washington DC.

Agricultural biotechnology has in the past been the poor relation of the human health care segment. Apart from the difficulties of genetically modifying organisms, indifference by investors and continued uncertainty surrounding its regulation have been barriers to commercialization.

However, two recent developments on the regulatory front could pave the way for agricultural biotechnology. In May, the FDA announced that foods developed using genetic engineering pose no new or special safety risks to the consumer and should be subject to the same standards of regulation as other foods (see Nature 357, 352; 1992). And earlier this month, the US Department of Agriculture announced plans to ease regulation of US field tests of genetically engineered crops (see Nature 360, 94; 1992). The report adds that optimism must be tempered by a need to inform the public about the safety and benefits of genetically engineered agricultural products.

The industry's record-setting performance in the public equity markets came during a time when the United States was in the grips of a recession. Investor interest was also piqued by the huge success of Amgen, whose stock price tripled in 1991. The romance with Wall Street lasted 18 months, to June 1992, during which time the industry raised more than $\$ 5$ billion in public equity and 67 of the now 225 public companies completed initial public offerings.

All that changed when Centocor's leading product veered off the regulatory track and the need to contain health care costs became an issue in the 1992 presidential election. Investors turned away from health care stocks and by June the financing window had slammed shut.

In the few months since then, there has been renewed interest in the biotechnology industry by venture capital firms, and Burrill predicts that 1992 could be a record year for start-up companies. The biotechnology industry is "awash with venture capital", he says, having raised $\$ 1.6$ billion during the first six months of this year compared with $\$ 1.3$ billion for the whole of 1991. Burrill capital to be invested in the second half of the year and the number of new start-up companies to exceed 80. Diane Gershon

* Biotech 93 Accelerating Commercialization: Ernst \&
Young's Seventh Annual Report on the Biotech Indus-
try (Ernst \& Young, San Francisco, California, 1992). expects a similar amount of new venture 